\title{
Leiomyoma of the bladder
}

\author{
Okwudili Emmanuel Muoka, ${ }^{1}$ Omorinsola Muoka, ${ }^{2}$ Pallon Daruwalla ${ }^{1}$
}

1 Department of Urology, Lincoln County Hospital, Lincoln, UK

${ }^{2}$ Department of Obstetric and Gynaecology, Lincoln County Hospital, Lincoln, UK

\section{Correspondence to} Okwudili Emmanuel Muoka, odimuoka@yahoo.com

\section{DESCRIPTION}

A 68-year-old lady normally fit and well who was referred with a history of a single episode of visible haematuria and intermittent lower urinary tract symptoms (LUTS) characterised by frequency, urgency and feeling of incomplete bladder emptying. She was investigated with a renal ultrasound which showed a vascular $37 \mathrm{~mm} \times 37 \mathrm{~mm}$ mixed echo-rounded mass lying centrally. She then had a flexible cystoscopy which demonstrated a solid-looking bladder tumour. Based on these she had a CT scan and a transurethral resection of the bladder mass. CT scan showed a well-circumscribed

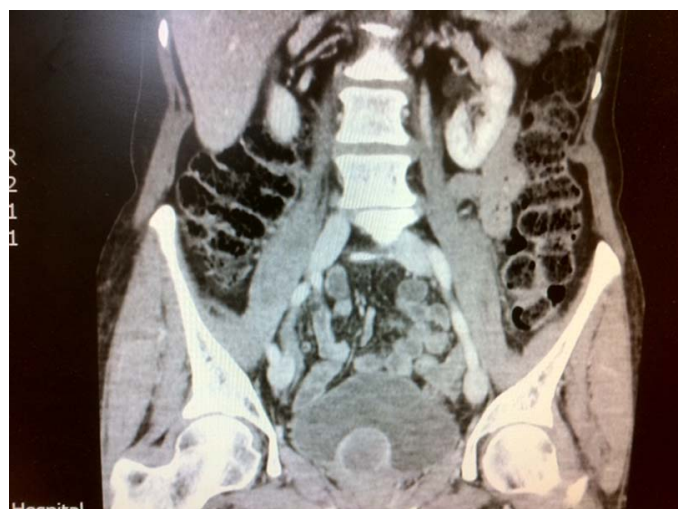

Figure 1 CT scan showing mass lesion.

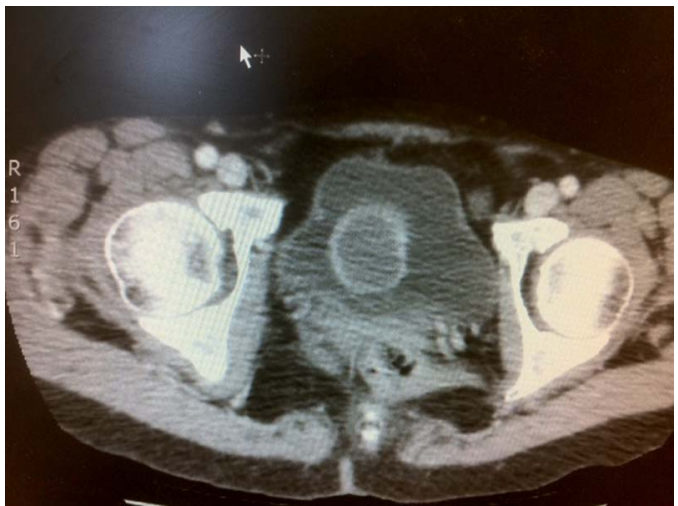

Figure 2 CT scan showing the lesion in relation to the bladder neck.

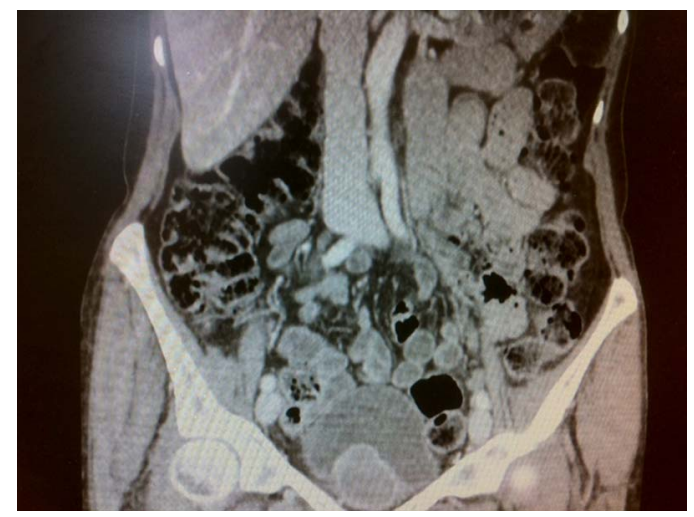

Figure 3 Another view of the lesion on CT scan.

bladder mass with central areas of low attenuation originating from the bladder neck (figures 1-3). The histology of the resection came back as showing a leiomyoma. Her LUTS resolved after the surgery. She had a check flexible cystoscopy 9 months after her surgery which showed no recurrence.

The CT images show a large well-circumscribed bladder lesion with no extravesical abnormality which is in keeping with a leiomyoma of the bladder. $^{12}$

\section{Learning points}

- Lower urinary symptoms can be presenting complaints of benign bladder tumours.

- Diagnosis of leiomyoma can be made with imaging techniques.

Competing interests None.

Patient consent Obtained.

Provenance and peer review Not commissioned; externally peer reviewed.

\section{REFERENCES}

1 Sudhakar PJ, Malik N, Malik A. Leiomyoma of bladder. Saudi J Kidney Dis Transp/ 2008;19:232-5.

2 Lin YW, Hwang TIS. Leiomyoma of urinary bladder: a case report and literature review. J Urol Roc 2001;12:96-8. 
Copyright 2013 BMJ Publishing Group. All rights reserved. For permission to reuse any of this content visit http://group.bmj.com/group/rights-licensing/permissions.

BMJ Case Report Fellows may re-use this article for personal use and teaching without any further permission.

Become a Fellow of BMJ Case Reports today and you can:

- Submit as many cases as you like

- Enjoy fast sympathetic peer review and rapid publication of accepted articles

- Access all the published articles

- Re-use any of the published material for personal use and teaching without further permission

For information on Institutional Fellowships contact consortiasales@bmjgroup.com

Visit casereports.bmj.com for more articles like this and to become a Fellow 